\title{
EVALUATION OF THE USE OF GLYCERIN AND SODIUM SILICATE IN WATER-BASED DRILLING FLUID
}

\author{
Francisco de A. Ribeiro Filho ${ }^{1}$, Fernando B. Mainier ${ }^{*}{ }^{凶}$, Luciane P. Costa Monteiro ${ }^{1}$ \\ ${ }^{1}$ Escola de Engenharia, Universidade Federal Fluminense, Niterói, Rio de Janeiro, Brazil
}

DOI: https://doi.org/10.29121/granthaalayah.v8.i5.2020.156
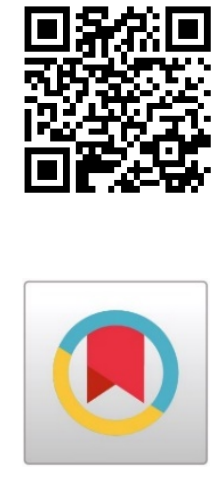

Article Type: Research Article

Article Citation: Francisco de A. Ribeiro Filho, Fernando B. Mainier, and Luciane P. Costa Monteiro. (2020). EVALUATION OF THE USE OF GLYCERIN AND SODIUM

SILICATE IN WATER-BASED DRILLING FLUID. International Journal of Research GRANTHAALAYAH, 8(5), 187-193. https://doi.org/10.29121/granthaa layah.v8.i5.2020.156

Received Date: 16 May 2020

Accepted Date: 31 May 2020

Keywords:

Drilling Fluid

Bi-Distilled Glycerin

Corrosion Inhibitor

Sodium Silicate

\begin{abstract}
Glycerin is a by-product of the transesterification reaction of vegetable oil to produce biodiesel. Glycerin production has increased as the number of biodiesel industries has grown. With features such as water solubility, low cost, and non-toxicity, it is a good substance for water-based drilling fluid formulations with less environmental contamination. The experiments were conducted using a drilling fluid commonly used in Brazil and were compared with glycerin additions at concentrations of $5,10,15$, and $20 \%$ by volume. Considering that as a result of the raw materials used, the biodiesel production routes produce a contaminated glycerin, it was decided to use a bi-distilled glycerin. In addition, sodium silicate, which uses industrial water or seawater, was added as a corrosion inhibitor due to its good performance and environmental non-toxicity. The sodium silicate was effective in combating corrosion without interfering with the fluid properties. The values of plastic viscosity, yield point, L3 (reading 3 $\mathrm{rpm}$ ), and gel strength, mostly presented results equal to or better than the original formulation of the fluid used as a comparison.
\end{abstract}

\section{INTRODUCTION}

Drilling fluid, or mud as it also called, is a mixture of natural and synthetic chemical compounds used to cool and lubricate the drill bit, clean the hole bottom, carry cuttings to the surface, control subsurface pressure, provide wellbore stability, and minimise formation damage, etc. Drill muds are generally classified into water-based mud (WBM) and oil-based mud (OBM). The WBM have greater environmental acceptance but must meet certain standards in order to be in contact with oil well drilling operations. OBM are extremely harmful to marine life therefore it is necessary to use risers to avoid the direct contact of the OBM with the seabed. Risers are tubular structures that connect the BOP (Blowout Preventer) to the turntable of the platform [1], [2], [3], [4].

The muds are usually composed of two phases: a dispersant (aqueous or organic), and a scattered phase, the complexity of which depends on the nature of the scattered products and its required functions.

Each drilling fluid has a specification for the operation to be completed safely and quickly. Therefore, it is necessary to present characteristics compatible with the lithology and types of rocks present in the drilling area.

The main requirements are [1], [2], [3], [4]

(C) 2020 The Author(s). This is an open access article distributed under the terms of the Creative Commons Attribution License, which permits unrestricted use, distribution, and reproduction in any medium, provided the original author and source are credited. 
- Chemical stability;

- Acceptance of any chemical and physical treatment;

- Be easily separated from gravel on the surface;

- Do not cause damage to formations;

- Be easy to pump;

- Have low degree of corrosion and abrasion;

- Facilitate geological interpretation of cuttings and well logging;

- Respect environmental laws;

- Low cost.

Most of the equipment used in drilling operations consisting of tanks, pumps, and pipes, is made of carbon steel. Special steels target mainly the contamination from rocks and water forming salinity, $\mathrm{CO}_{2}$ and $\mathrm{H}_{2} \mathrm{~S}$ [1], [5], [6].

The objective of this work is centred on the evaluation of formulated drilling fluids containing glycerin and sodium silicate. Glycerin is a by-product of biodiesel production and its raw material is oils from soybean, peanuts, corn, sunflower, etc.

Considering that in Brazil the biodiesel program aims to incorporate vegetable raw material (oilseeds) through the transesterification synthesis into conventional diesel oil (2 to 5\%), it is valid to state that there is a large availability of glycerin byproducts at a low cost [7], [8], [9] while sodium silicate is a corrosion inhibitor that has shown excellent performance for saline solutions.

\section{MATERIALS AND METHODS}

As previously mentioned, glycerin is a by-product of biodiesel production. The process consists essentially of oil extraction from oilseeds (soybean, sunflower, peanut, cotton, etc.) by pressing and solvent extraction. In order to identify the best industrial options for biodiesel production, the composition of the triglyceride-rich produced oil, which largely depends on the etymology of the plant species, as well as the seed oil content and oil productivity per planted area, have to be taken into consideration.

The transesterification process consists of the stoichiometric reaction of three moles of low molecular weight alcohol (methanol or ethanol) for each mole of triglyceride in the oil, in the presence of a catalyst and at a temperature of 50 to $60^{\circ} \mathrm{C}$, as shown in Figure 1. Some variables influence the transesterification reaction, namely: reagent purity, alcohol/oil molar ratio, reaction temperature, catalyst, and agitation [7], [8], [9].

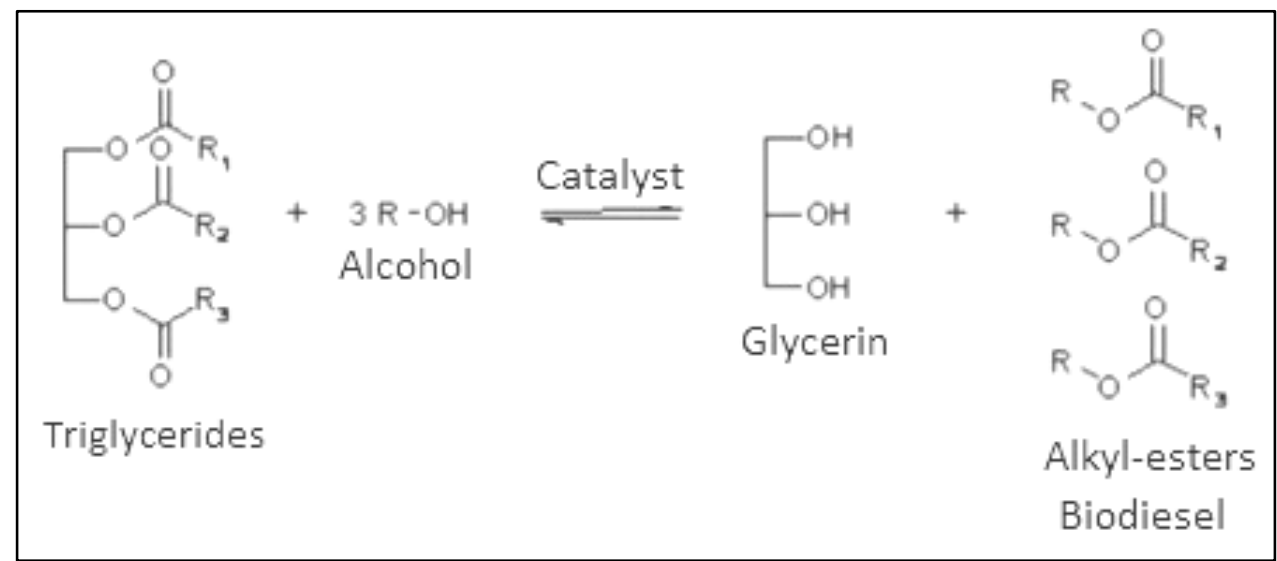

Figure 1: Transesterification reaction

Given this production process it can be assumed that glycerin marketed as a by-product has a series of contaminants from the seeds used (raw material), as well as the operating conditions of the processing (extraction and purification).

The mud used for this experiment is polymeric with a good performance considering the shale lithological standard. The aim is, at least, to maintain the rheological parameters of the original fluid, but reduce the xanthan 
gum concentration by the addition of bi-distilled glycerin. The option of using the bi-distilled glycerin rather than a commercial product was that the commercial glycerins that were analysed had several constituents that might hinder the process of evaluating the mud properties.

Glycerol or glycerin is a colourless, odourless, viscous liquid that is sweet-tasting and non-toxic. The main physicochemical properties of the glycerin used in the assays are presented in Table 1 [10].

Table 1: Physicochemical properties of glycerin [10].

\begin{tabular}{|l|l|}
\hline Molecular formula & $\mathrm{C}_{3} \mathrm{H}_{8} \mathrm{O}_{3} ; \mathrm{CH}_{2} \mathrm{OH}-\mathrm{CHOH}-\mathrm{CH}_{2} \mathrm{OH}$ \\
\hline Molecular Weight & $92.09 \mathrm{~g} / \mathrm{mol}$ \\
\hline Boiling point & $290{ }^{\circ} \mathrm{C}$ \\
\hline Flash Point & $160^{\circ} \mathrm{C}$ \\
\hline Melting point & $18{ }^{\circ} \mathrm{C}$ \\
\hline Viscosity & $1410 \mathrm{mPa} . \mathrm{s}$ at $20^{\circ} \mathrm{C}$ \\
\hline Density & $1.26 \mathrm{~g} / \mathrm{cm}^{3}$ at $20^{\circ} \mathrm{C}$ \\
\hline
\end{tabular}

High purity sodium silicate hydrate $\left(\mathrm{Na}_{2} \mathrm{SiO}_{3} \cdot 9 \mathrm{H}_{2} \mathrm{O}\right)$ was used as a corrosion inhibitor. This corrosion inhibitor was chosen because it is inorganic, non-toxic, and has had good results in the protection of carbon steel in saline solutions [11].

Table 2, below, shows the standard drilling fluid formulation (base fluid) used as a reference and the glycerin and sodium silicate additions made to this standard formulation.

Table 2: Drilling Fluids Composition

\begin{tabular}{|c|c|c|c|c|c|c|}
\hline \multirow[t]{2}{*}{ Substances } & \multirow[t]{2}{*}{ Function } & \multirow{2}{*}{$\begin{array}{l}\text { Base } \\
\text { fluid }\end{array}$} & \multicolumn{4}{|c|}{ Adding glycerin to base fluid } \\
\hline & & & $5 \%$ & $10 \%$ & $15 \%$ & $20 \%$ \\
\hline Water, v/v\% & Continuous phase & 49 & 44 & 39 & 34 & 29 \\
\hline Bi-distilled glycerin, $\mathrm{v} / \mathrm{v} \%$ & Continuous phase & 0 & 5 & 10 & 15 & 20 \\
\hline Saturated sodium chloride brine, v/v\% & Continuous phase & 40 & 40 & 40 & 40 & 40 \\
\hline Sodium bicarbonate, $\mathrm{g} / \mathrm{L}$ & Hardness removal & 0.57 & 0.57 & 0.57 & 0.57 & 0.57 \\
\hline Polydimethylsiloxane, g/L & Defoamer & 0.57 & 0.57 & 0.57 & 0.57 & 0.57 \\
\hline Xanthan gum, g/L & Viscosifier & 2.28 & 1.43 & 1.43 & 1.43 & $\begin{array}{l}1.43 \\
1.71\end{array}$ \\
\hline $\begin{array}{l}\text { Polyanionic cellulose - low Viscosity, } \\
\text { g/L }\end{array}$ & Filtration control agent & 5.70 & 5.70 & 5.70 & 5.70 & 5.70 \\
\hline Hydroxypropyl starch, g/L & Filtration control agent & 11.41 & 11.41 & 11.41 & 11.41 & 11.41 \\
\hline Magnesium oxide, g/L & Alkaline agent & 1.42 & 1.42 & 1.42 & 1.42 & 1.42 \\
\hline Potassium chloride, g/L & Shale inhibitor & 42.80 & 42.80 & 42.80 & 42.80 & 42.80 \\
\hline Polyamine, g/L & Swelling agent & 17.12 & 17.12 & 17.12 & 17.12 & 17.12 \\
\hline Glutaraldehyde, g/L & Biocide & 0.85 & 0.85 & 0.85 & 0.85 & 0.85 \\
\hline Calcium carbonate, $\mathrm{g} / \mathrm{L}$ & $\begin{array}{l}\text { Weighting / bridging } \\
\text { agent }\end{array}$ & 114.12 & 114.12 & 99.86 & 85.59 & 71.32 \\
\hline Polyol ester oil, g/L & Bit balling preventer & 0.85 & 0.85 & 0.85 & 0.85 & 0.85 \\
\hline Polyethylene glycol oleate, g/L & Lubricant & 14.26 & 14.26 & 14.26 & 14.26 & 14.26 \\
\hline Sodium silicate, $\mathrm{g} / \mathrm{L}$ & Corrosion inhibitor & 2.28 & 2.28 & 2.28 & 2.28 & 2.28 \\
\hline
\end{tabular}

A rotational viscometer with a mud cup was used to measure the rheological properties. The mud cup heats the fluid to the desired temperature, which is $120^{\circ} \mathrm{F}\left(48.88^{\circ} \mathrm{C}\right)$ according to the American Petroleum Institute (API) [12]. Measurements were taken at the following speeds in revolutions per minute: 600, 300, 200, 100, 6 and 3. With these measurements, it is possible to determine the plastic viscosity and the yield point using the formulae below:

Plastic Viscosity (PV) = L $600-\mathrm{L} 300$.

Yield Point (YP) = PV - L 300. 
For the base fluid, the xanthan gum concentration was $2.28 \mathrm{~g} / \mathrm{L}$. After manufacture, the fluids were placed in scroll caps and inserted in an oven for 16 hours to simulate their ageing.

The referral values for the main properties are summarised in Table 3.

Table 3: Properties and their target values

\begin{tabular}{|l|l|}
\hline Properties & Referral values* \\
\hline Plastic Viscosity & $15-40 \mathrm{cP}$ \\
\hline Yield Point & $15-40 \mathrm{lb} / 100 \mathrm{ft}^{2}$ \\
\hline Gel Strength $(10$ seconds) & $7-15 \mathrm{lb} / 100 \mathrm{ft}^{2}$ \\
\hline Gel Strength (10 minutes) & $8-25 \mathrm{lb} / 100 \mathrm{ft}^{2}$ \\
\hline L3, rpm & $7-10$ \\
\hline Fluid Density & $9.8-10.2 \mathrm{lb} /$ gal \\
\hline
\end{tabular}

*Considering the fluid under operation

AISI 1020 carbon coupon ( $0.21 \%$ of carbon) mass loss assays were performed by immersion in the base fluids and base fluids with the addition of $20 \% \mathrm{v} / \mathrm{v} \%$ glycerin for 10 days.

\section{RESULTS AND DISCUSSIONS}

The objective of using glycerin, besides giving value to the product, is to keep the rheological parameters constant, and to decrease the concentration of xanthan gum in the fluid formulation, with the aim to have a good rheology for the drilling of an oil well.

The results of laboratory tests that can determine the conditions of the use of drilling fluid in oil well drilling operations are presented below in Figures 1, 2 and 3.

Plastic viscosity is directly linked to the internal resistance exerted by a fluid to flow. The solids content in a drilling fluid influences the particle friction, a higher solid content results in a higher particle friction, which results in a higher plastic viscosity [13].

The Yield point (YP) indicates the ability of the fluid to carry the cuttings generated by the drilling up to the surface. It is the minimum effort required to initiate the fluid movement [14].

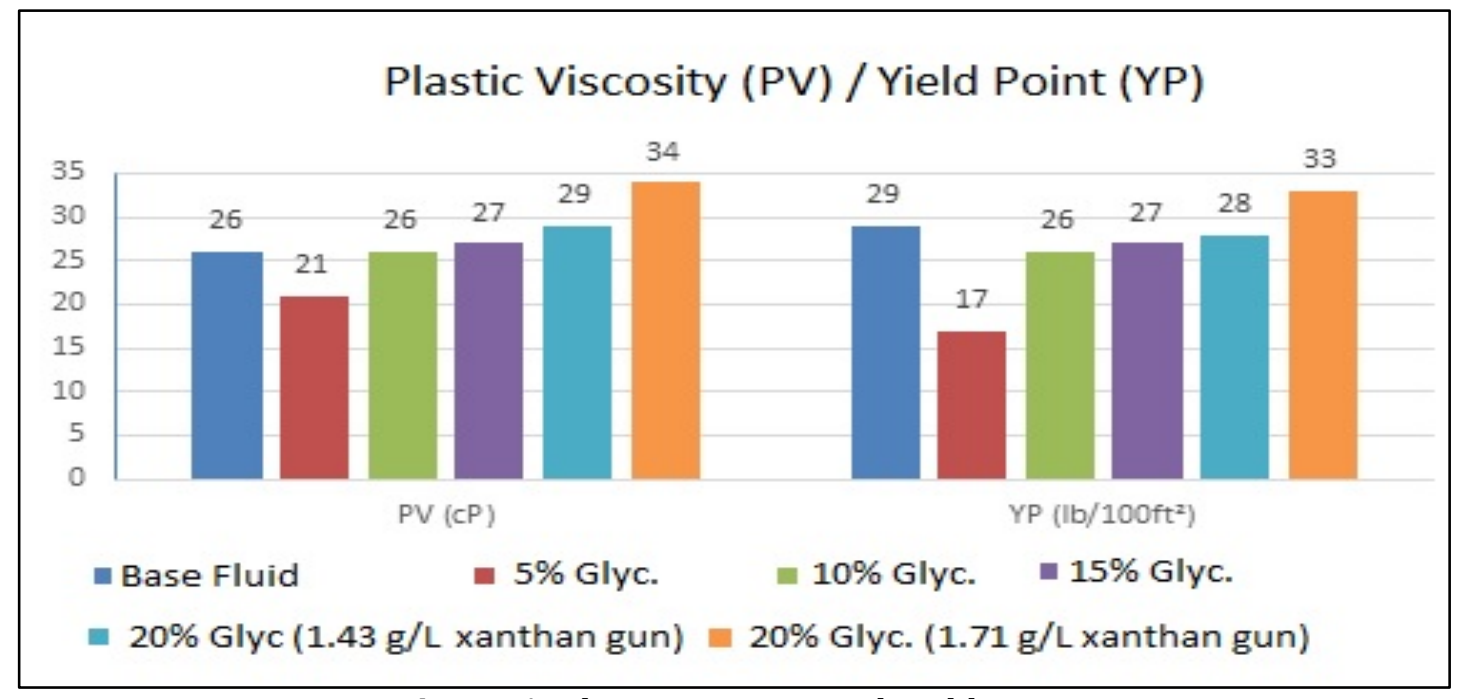

Figure 1: Plastic viscosity and Yield point

All values obtained regarding the plastic viscosity (PV) of the fluid and the Yield Point (YP) were within the range considered ideal for the formulation of the base fluid. Fluids with a $10 \%$ bi-distilled glycerin content had values similar to the base fluid. Compared to the $20 \%$ content of bi-distilled glycerin, the influence of the xanthan gum concentration on the properties is more evident with an increase, as seen when comparing the concentrations of $1.43 \mathrm{~g} / \mathrm{L}$ and $1.71 \mathrm{~g} / \mathrm{L}$. 
Francisco de A. Ribeiro Filho, Fernando B. Mainier, and Luciane P. Costa Monteiro

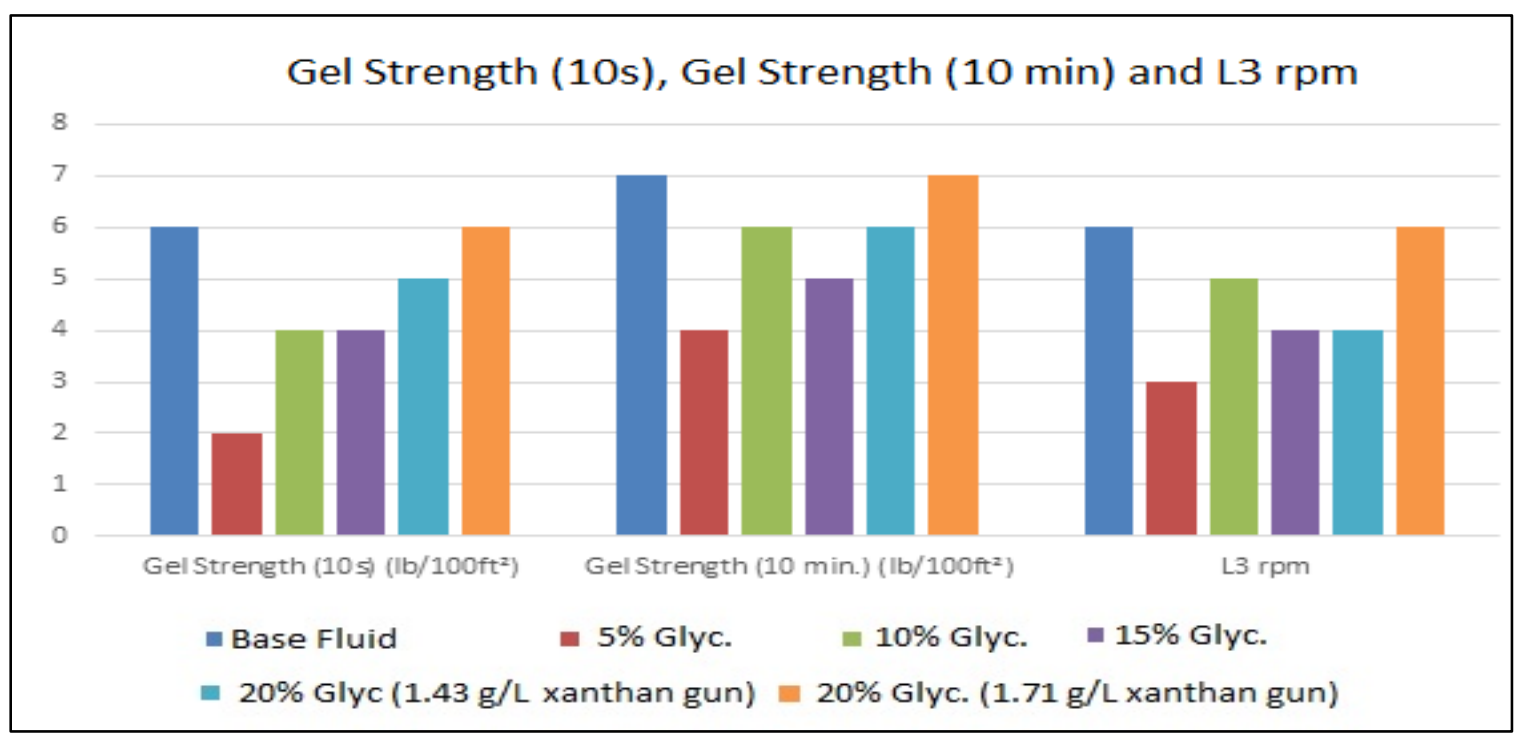

Figure 2: Gel strength and L3 rpm results

Gel strength is a rheological parameter that indicates the degree of gelification due to the electrical interaction between the dispersed particles. The gel strength 10s measures the resistance to flow of the fluid, while the gel strength 10 min. measures the resistance of the fluid to restart the flow after it has been at rest for a while. The difference between them indicates the degree of fluid thixotropic [2], [15], [16].

The L3 rpm reading is used to determine the 10 seconds and 10 minutes gel strengths, however, the conditions under which they are measured are different. The 10-second gel has a lower gel level than that for 10 minutes because the particle aggregation is lower so resulting in different values.

Only the values obtained in the fluid with $20 \%$ bi-distilled glycerin and $1.71 \mathrm{~g} / \mathrm{L}$ xanthan gum reached the referral value.

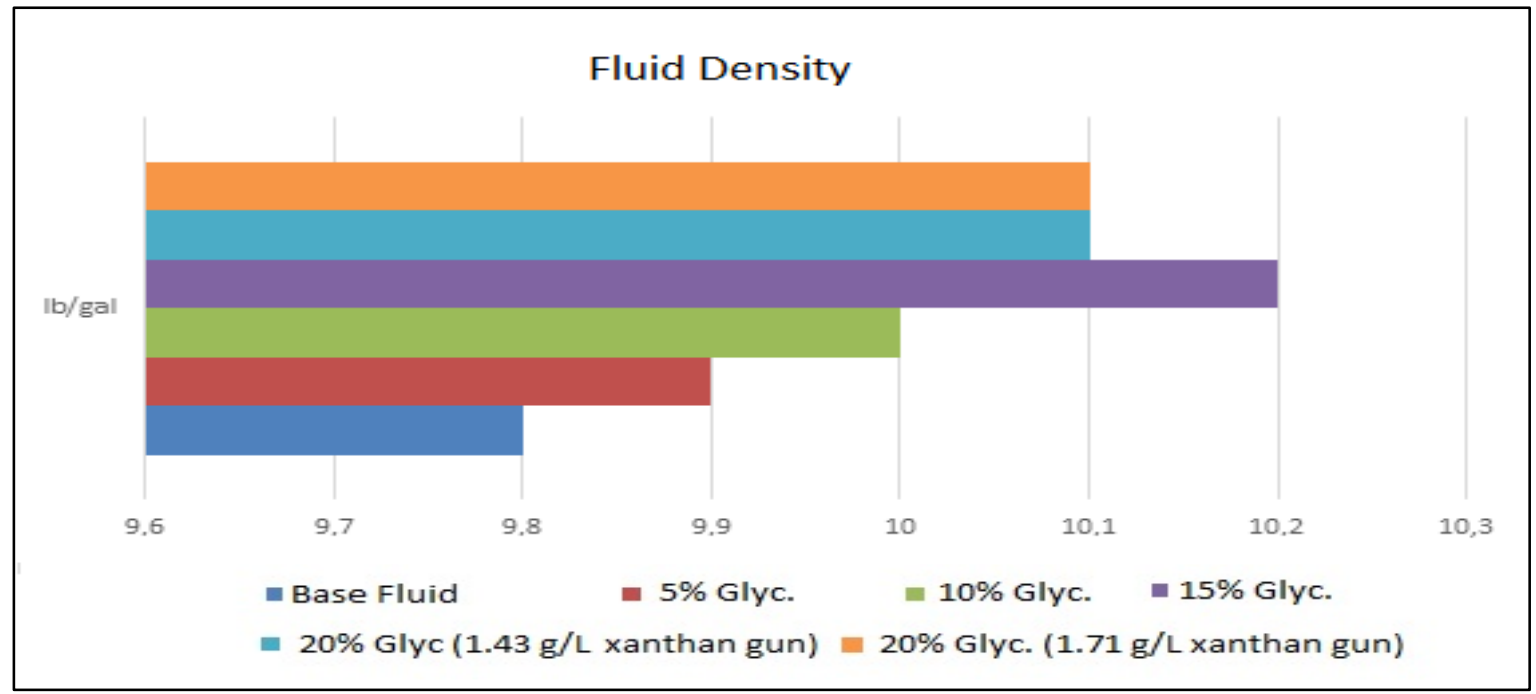

Figure 3: Fluid density results

The fluid density values fluctuated according to the bi-distilled glycerin content, however this is because the calcium carbonate concentrations in the fluids were different, as can be seen in Table 1.

The desired density value for the project can be achieved by increasing or decreasing the amount of calcium carbonate accordingly.

The mass losses in carbon steel coupons were negligible, evidencing that the sodium silicate addition, at the concentration of $2.28 \mathrm{~g} / \mathrm{L}$, offers excellent anti-corrosion protection to the carbon steel, validated by mass loss assays performed using sodium chloride solution at $3.5 \%$ in mass [11]. 


\section{CONCLUSIONS}

The fluid parameters were generally within, or very close to the, stipulated ranges, which is satisfactory for laboratory testing. In a field simulation, the rheology would probably be slightly higher due to the solids that aggregate during drilling.

From the tests performed with bi-distilled glycerin on a specific fluid formulation, it can be concluded that the presence of bi-distilled glycerin contributes to the fluid density, besides increasing the plastic viscosity and yield point parameters. The fluid with a concentration of $1.71 \mathrm{~g} / \mathrm{L}$ xanthan gum and $20 \%$ bi-distilled glycerin resulted in a rheology similar to that of the base fluid $(2.28 \mathrm{~g} / \mathrm{L}$ of xanthan gum), but there are possible scenarios for the results obtained with the concentration of $1.43 \mathrm{~g} / \mathrm{L}$ xanthan gum.

The laboratory performance of the fluid can be equated with an OBM. However, the bi-distilled glycerin fluid is far less harmful to the environment, although the stability of the OBM is greater for drilling in saline formations and also in the pre-salt formations.

Bi-distilled glycerin has an advantage over crude glycerin because its properties have a standard which is not presented by crude glycerin. In addition, the purity percentage is close to $99 \%$, which is higher than that of crude glycerin which has an average $30 \%$ of impurities.

\section{SOURCES OF FUNDING}

None.

\section{CONFLICT OF INTEREST}

None.

\section{ACKNOWLEDGMENT}

None.

\section{REFERENCES}

[1] Fink, J. K. Oil field chemicals. New York: Gulf Professional Publishing, 2003.

[2] Caenn, R. \& Chillingar, G. V. Drilling fluids: State of the art. Journal of Petroleum Science and Engineering, 14(34), 1996, 221-230. https://doi.org/10.1016/0920-4105(95)00051-8.

[3] Schaffel, S. B. A questão ambiental na etapa de perfuração de poços marítimos de óleo e gás no Brasil (The environmental issue in the drilling stage of oil and gas maritime wells in Brazil). Dissertação, COPPE/UFRJ, Rio de Janeiro, Brazil, 2002.(in Portuguese).

[4] Khodja, M., Khodja-Saber, M., Canselier, J. P., Cohaut, N., \& Bergaya, F. Drilling fluid technology: performances and environmental considerations. In: Products and services; from R\&D to final solutions, 2010, IntechOpen.

[5] Al Juhaiman, L. A.; Mustafa, A. A.; Mekhamer, W. K. Polyvinyl pyrrolidone as a green corrosion inhibitor for carbon steel in alkaline solutions containing NaCl. Anti-Corrosion Methods and Materials, n. 1, v. 60, 2013, 2836, https://doi.org/10.1108/00035591311287429

[6] Dhiman, A. S. Rheological properties \& corrosion characteristics of drilling mud additives. Halifax: Dalhousie University, 2012.

[7] Sinha, S., Agarwal, A. K., \& Garg, S. Biodiesel development from rice bran oil: Transesterification process optimization and fuel characterization. Energy conversion and management, 49(5), 2008, 1248-1257. https://doi.org/10.1016/j.enconman.2007.08.010

[8] Meher, L. C., Sagar, D. V., \& Naik, S. N. Technical aspects of biodiesel production by transesterification -a review. Renewable and sustainable energy reviews, 10(3), 2006, 248-268. https://doi.org/10.1016/j.rser.2004.09.002 
[9] Garcia, E., Laca, M., Pérez, E., Garrido, A., \& Peinado, J. New class of acetal derived from glycerin as a biodiesel fuel component. Energy \& fuels, 22(6), 2008, 4274-4280. https://doi.org/10.1021/ef800477m

[10] U.S. National Library of Medicine, National Center for Biotechnology Information, https://pubchem.ncbi.nlm.nih.gov/compound/glycerol.

[11] Mainier, F. B., Figueiredo, A. A., de Freitas, A. E. R., \& de Alencar Junior, A. A. M. The Use of Sodium Silicate as a Corrosion Inhibitor in a Saline Drilling Fluid: A Nonaggressive Option to the Environment. Journal of Environmental Protection, 7(13), 2016, 2025. http://dx.doi.org/10.4236/jep.2016.713157

[12] American Petroleum Institute, Purchasing Guidelines, Specification 13A 18th Edition, Specification for Drilling Fluids -Specifications and Testing, August 2010, https://www.api.org.

[13] Félix, T.F., Vidal, E.L.F., Garcia, R.B., Costa, M.; Girão, J.H.S.; Pereira, E. Desenvolvimento de fluidos de perfuração à base de água com alta capacidade de inibição e alta lubricidade (Development of high inhibitory and high lubricity water based drilling fluids); 4o PDPETRO, Campinas, SP, Brazil, 2007. ( Portuguese).

[14] Mendonça, J.C.M., Medeiros, R.C.A., Amorim, L.V. Influência da argila organofilica nas propriedades de fluidos de perfuração sintéticos produzidos com emulsificante a base da borra de óleo de soja (Influence of organophilic clay on the properties of synthetic drilling fluids produced with soybean oil sludge emulsifier). 23ํㅡㄹ Congresso Brasileiro de Engenharia e Ciências dos Materiais, 4-8 de novembro, Paraná, Brazil, 2018. (in Portuguese).

[15] Jachnik, R. Drilling Fluid Thixotropy \& Relevance. Stress, 2000, 1500.

[16] Maxey, J. Thixotropy and yield stress behavior in drilling fluids. In AADE 2007 Drilling Fluids Conference, april (AADE-07-NTCE-37, 2007. 